\title{
Integrating sugarcane molasses into sequential cellulosic biofuel production based on SSF process of high solid loading
}

\author{
Meishan Fan, Shuaishuai Zhang, Guangying Ye, Hongdan Zhang ${ }^{*}$ and Jun Xie*
}

\begin{abstract}
Background: Sugarcane bagasse (SCB) is one of the most promising lignocellulosic biomasses for use in the production of biofuels. However, bioethanol production from pure SCB fermentation is still limited by its high process cost and low fermentation efficiency. Sugarcane molasses, as a carbohydrate-rich biomass, can provide fermentable sugars for ethanol production. Herein, to reduce high processing costs, molasses was integrated into lignocellulosic ethanol production in batch modes to improve the fermentation system and to boost the final ethanol concentration and yield.

Results: The co-fermentation of pretreated SCB and molasses at ratios of 3:1 (mixture A) and 1:1 (mixture B) were conducted at solid loadings of $12 \%$ to $32 \%$, and the fermentation of pretreated SCB alone at the same solid loading was also compared. At a solid loading of $32 \%$, the ethanol concentrations of $64.10 \mathrm{~g} / \mathrm{L}, 74.69 \mathrm{~g} / \mathrm{L}$, and $75.64 \mathrm{~g} / \mathrm{L}$ were obtained from pure SCB, mixture $A$, and mixture $B$, respectively. To further boost the ethanol concentration, the fermentation of mixture B (1:1), with higher solid loading from 36 to $48 \%$, was also implemented. The highest ethanol concentration of $94.20 \mathrm{~g} / \mathrm{L}$ was generated at a high solid loading of $44 \%$, with an ethanol yield of $72.37 \%$. In addition, after evaporation, the wastewater could be converted to biogas by anaerobic digestion. The final methane production of $312.14 \mathrm{~mL} / \mathrm{g}$ volatile solids (VS) was obtained, and the final chemical oxygen demand removal and VS degradation efficiency was $85.9 \%$ and $95.9 \%$, respectively.
\end{abstract}

Conclusions: Molasses could provide a good environment for the growth of yeast and inoculum. Integrating sugarcane molasses into sequential cellulosic biofuel production could improve the utilization of biomass resources.

Keywords: Bioethanol, Biogas, Co-fermentation, High solid loading, Sugarcane bagasse, Sugarcane molasses

\section{Background}

Bioethanol, as a replacement and additive of gasoline, is a remarkable type of biofuel. Lignocellulosic biomass is regarded as a potential material for the production of cellulosic ethanol due to its relatively low cost and because it prevents the diversion of food crops to the production of bioethanol [1]. However, some disadvantages have limited the development of bioethanol production from

\footnotetext{
${ }^{*}$ Correspondence: hdzhang@scau.edu.cn; xiejun@scau.edu.cn College of Forestry and Landscape Architecture, Guangdong Engineering Technology Research Center of Agricultural and Forestry Biomass, Key Laboratory of Energy Plants Resource and Utilization, Ministry of Agriculture, South China Agricultural University, Guangzhou 510642, People's Republic of China
}

lignocellulosic biomass, such as high enzyme costs and lower ethanol titers and yields [2,3]. Currently, several methods have been proposed for the integration of grains or sugar juice to enhance the initial sugar concentration and improve the subsequent ethanol production [4]. Xu et al. [5] investigated the influence of starchy substrate addition on cellulosic ethanol production, demonstrating the improvement of the final ethanol concentration from 6.9 to $18.1 \mathrm{~g} / \mathrm{L}$. Ye et al. [6] obtained a final ethanol concentration of $82.83 \mathrm{~g} / \mathrm{L}$ by the co-fermentation of sugarcane bagasse and Dioscorea composita hemls. Erdei et al. [7] achieved 99\% of the theoretical ethanol yield using the mixtures of wheat straw and wheat meal. Damay et al. [8] found that mixing first-generation sugars

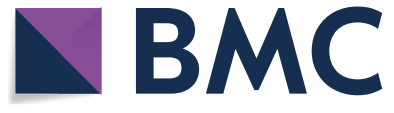

(c) The Author(s) 2018. This article is distributed under the terms of the Creative Commons Attribution 4.0 International License (http://creativecommons.org/licenses/by/4.0/), which permits unrestricted use, distribution, and reproduction in any medium, provided you give appropriate credit to the original author(s) and the source, provide a link to the Creative Commons license, and indicate if changes were made. The Creative Commons Public Domain Dedication waiver (http://creativecommons.org/ publicdomain/zero/1.0/) applies to the data made available in this article, unless otherwise stated. 
and second-generation sugars could eliminate the effect of pretreatment inhibitors in the fermentation process to obtain ethanol yields of greater than $90 \%$. Though significant advances have been made in improving ethanol production, a comprehensive understanding of the cofermentation of sugarcane bagasse (SCB) and sugarcane molasses at different solid loadings remains unclear.

Sugarcane is the most important sugar crop in the tropical regions of the world, and it is widely planted in southern China [6]. SCB and molasses are both by-products of the cane sugar production. In China, approximately 36 million tons of sugarcane bagasse and 4 million tons of molasses are produced every year during sugar processing [9]. SCB, as the fibrous substance produced after juice extraction from sugarcane, has the characteristics of avoiding feedstock handling, being easy to collect and can be used directly in the sugar mill (i.e., no transportation costs) [10]. Due to the high cellulose contents of SCB, it is an attractive substrate for ethanol production. Molasses, containing a high concentration of fermentable sugars, is the noncrystallizable residue left after sugar crystallization from cane juice. It is usually used in alcohol distilleries without the steps of pretreatment and saccharification $[11,12]$. Since SCB and molasses are produced at the same time in sugar production, co-fermentation of SCB and molasses as complementary materials would achieve the comprehensive economic benefits of sugarcane/sugar industry and gain higher resource utilization.

Due to the intact structure of sugarcane bagasse, pretreatment is conducted to effectively remove lignin and hemicellulose, disrupt the cellulose crystallinity, and increase the porosity of the biomass [13, 14]. Recently, various pretreatments have been proposed to separate the lignin and hemicelluloses from the lignocellulosic biomass, such as using acid, alkaline, steam explosion, wet oxidation, and organosolv techniques [15]. Compared with the other pretreatment methods, alkali pretreatment is more favorable because of its simple device, convenient operation, low cost, and high efficiency [13]. After alkali pretreatment, the contents of glucan and xylan in SCB were found to be increased due to delignification, making cellulose and hemicellulose available for the enzymatic degradation and resulting in an increase of sugar yield during the enzymatic saccharification [16]. Mcintosh et al. [17] observed a high rate of enzymatic saccharification and a high ethanol yield when using dilute alkaline pretreated wheat and sorghum straw as substrates.

Simultaneous saccharification and fermentation (SSF) is able to rapidly convert sugars into ethanol as soon as the saccharification of lignocellulosic biomass begins, which would relieve the inhibitory effect of high sugar contents on saccharomycetes [18]. Moreover, SSF has been extensively applied, because it can reduce the cost of equipment capital and the risk of contamination, as well as shorten the processing time compared with separate hydrolysis and fermentation (SHF) [19].

In general, the amount of biomass loadings is increased to meet a minimum economical ethanol distillation of $40 \mathrm{~g} / \mathrm{L}$ [3]. A high biomass loading could enhance fermentable sugars and reduce the economic cost of ethanol distillation. However, it was shown that the ethanol yield decreased when the biomass loading was greater than $15 \%(w / w)$ [20]. In addition, high solid loadings mean that there is a large amount of biomass for fermentation, which increases the mixing difficulty and power consumption of stirred tank reactors $[21,22]$. Furthermore, the concentration of byproducts (such as glycerol, lactic acid, and acetic acid) increases as the increment of biomass loading. These inhibitors have a negative impact on the fermenting microorganism [23]. It remains a challenge for the cellulosic ethanol production to achieve a high final ethanol concentration due to the difficulty of applying a high solid loading process in SSF in batch-mode reactions [24]. Hence, co-fermentation of mixed substrates would be a promising approach that could increase fermentable sugar concentrations and consequently result in a high final ethanol titer [25].

After the fermentation, the ethanol is collected and the residues in the stillage can be incinerated to produce steam or converted into animal feed. However, these methods cannot efficiently meet the requirements of sustainable manner [26]. It has been reported that stillage production is $10-20$ times more than the volume of ethanol production [27]. Therefore, it is necessary to develop an environmentally friendly method for the utilization of stillage waste. Recently, anaerobic digestion has been recognized as an effective and feasible method to economically use the stillage [28]. The biogas produced from ethanol fermentation residues could be converted to another type of biofuel, which could provide renewable energy and reduce environmental pollution problems $[29,30]$.

In this research, compared with only pretreated SCB fermentation, two ratios of alkali-pretreated SCB and molasses were used to evaluate their influence on ethanol concentrations and yields during the SSF process. Furthermore, higher solid loadings of mixtures of pretreated SCB and molasses, with a ratio of 1:1, were investigated to help increase the ethanol concentration and to obtain a suitable conversion rate. In addition, the stillage was sequentially digested for biogas production to achieve a comprehensive biomass utilization. 


\section{Results and discussion}

\section{Chemical analysis of materials}

As shown in Table 1, the molasses contained 9\% of fructose, $6 \%$ of glucose, and $23 \%$ of sucrose $(w / w)$. The chemical composition of raw SCB used in this experiment contained $38.43 \%$ cellulose, $24.30 \%$ xylan, $25.98 \%$ Klason lignin, and $6.14 \%$ acid soluble lignin (ASL). After alkali pretreatment, the composition of SCB was significantly altered, with a solid yield of $82.2 \%$. The loss of solids was ascribed to the degradation of lignin. Owing to the delignification, the content of cellulose and xylan increased to $53.01 \%$ and $29.36 \%$, respectively. The Klason lignin and ASL contents were decreased to $10.05 \%$ and $4.01 \%$, respectively, which was in accordance with the results of decreased solid yields. Delignification provided a greater cellulose content of substrates available for enzymatic hydrolysis and improved the efficiency at high solid loadings [6].

\section{The fermentation of pure pretreated SCB}

It is known to us that SCB is an excellent lignocellulosic biomass for ethanol production thanks to its relatively low lignin content and high cellulose content when using appropriate pretreatments [31]. Figure 1 depicts the ethanol concentration under different solid loadings, from 12 to $32 \%(\mathrm{w} / \mathrm{v})$, as the fermentation time was extended during SSF. As shown, the ethanol concentration rapidly increased in the first $24 \mathrm{~h}$ owing to the high saccharification of the lignocellulosic biomass [32]. For the low loading of $12 \%$ to $20 \%$, the concentration rose slightly and stabilized after $72 \mathrm{~h}$. However, for the high loading of $24 \%$ to $32 \%$, as the hydrolysis time was extended from 24 to $48 \mathrm{~h}$, a very slow fermentation rate of less than $0.2 \mathrm{~g} / \mathrm{L} / \mathrm{h}$ was observed. This phenomenon could be due to the limitations of mass transfer or inhibition from the accumulated byproducts at high solid loadings [33]. Though the fermentation rate was low, the ethanol concentration increased gradually as the fermentation time was prolonged. The final ethanol concentration reached $27.69 \mathrm{~g} / \mathrm{L}, 33.37 \mathrm{~g} / \mathrm{L}, 43.67 \mathrm{~g} / \mathrm{L}$, $54.76 \mathrm{~g} / \mathrm{L}, 61.52 \mathrm{~g} / \mathrm{L}$, and $62.01 \mathrm{~g} / \mathrm{L}$, as the solid loading increased from 12 to $32 \%$. The maximum ethanol concentration $(62.01 \mathrm{~g} / \mathrm{L})$ was achieved at a loading of $32 \%$, with an ethanol yield of $64.1 \%$, whereas a higher ethanol yield of $75.67 \%$ was obtained at a loading of $12 \%$. These results suggest that fermentable yields decreased with the increase of biomass loading.

All ethanol concentrations of high-gravity fermentation reached the commercial production titers (> $40 \mathrm{~g} / \mathrm{L}$ ) except for the loadings of $12 \%$ and $16 \%$. However, the saccharification and fermentation of lignocellulosic biomass required a longer time $(120 \mathrm{~h})$, and the liquidity of the reactant was limited by high substrate loadings, which increased the cost and reduced the economic efficiency [34]. Hence, it is unreasonable to generate higher ethanol concentrations by increasing only the solid loadings of pretreated SCB. Meanwhile, the fermentation of pretreated SCB alone would not be beneficial for yeast growth due to the lack of necessary nutrients. Hence, it is necessary to integrate substrates containing nutrient contents and high concentrations of sugars into the SCB ethanol fermentation process, thereby improving the ethanol concentration and yield [5].

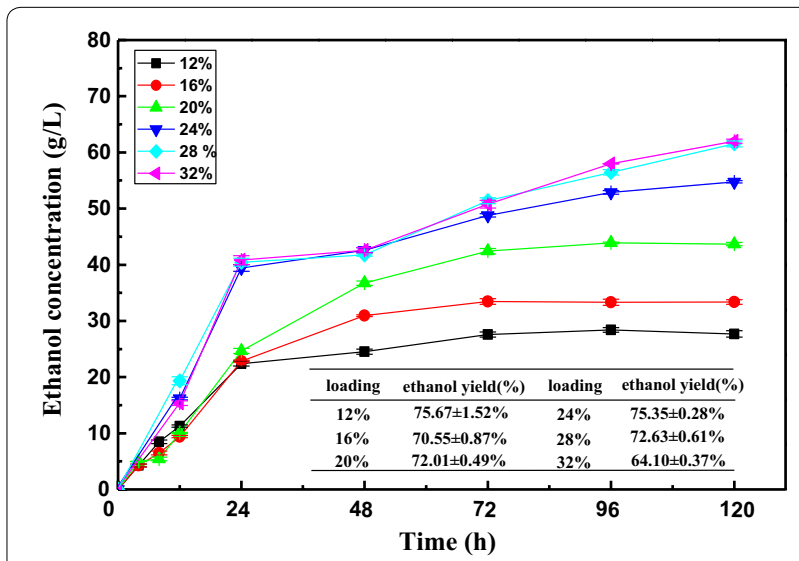

Fig. 1 Ethanol concentrations and yields of SCB at different solid loadings in SSF

Table 1 Chemical composition of the raw and pretreated SCB

\begin{tabular}{|c|c|c|c|c|c|c|c|c|}
\hline Materials & $\begin{array}{l}\text { Cellulose } \\
\%^{d b}\end{array}$ & $\begin{array}{l}\text { Xylan } \\
\% \text { db }\end{array}$ & $\begin{array}{l}\text { Klason lignin } \\
\%^{\mathrm{db}}\end{array}$ & $\begin{array}{l}\text { ASL } \\
\%^{d b}\end{array}$ & $\begin{array}{l}\text { Fructose } \\
\% \text { wb }\end{array}$ & $\begin{array}{l}\text { Glucose } \\
\% \text { wb }\end{array}$ & $\begin{array}{l}\text { Sucrose } \\
\%^{\text {wb }}\end{array}$ & $\begin{array}{l}\text { Solid yield } \\
\%\end{array}$ \\
\hline Molasses & & & & & $9 \pm 0.4$ & $6 \pm 0.2$ & $23 \pm 0.7$ & $30.61 \pm 0.1^{w b}$ \\
\hline Untreated SCB & $38.43 \pm 0.50$ & $24.3 \pm 0.22$ & $25.98 \pm 0.14$ & $6.14 \pm 0.41$ & & & & \\
\hline Pretreated SCB & $53.01 \pm 0.70$ & $29.36 \pm 0.30$ & $10.05 \pm 0.05$ & $4.01 \pm 0.03$ & & & & $84.1 \pm 0.5^{\mathrm{db}}$ \\
\hline
\end{tabular}

$A S L$ acid soluble lignin

$\mathrm{db}$ : means dry basis

wb : means wet basis 


\section{The co-fermentation of pretreated SCB and molasses}

Molasses contains a high content of fermentable sugars and other nutrients, which are beneficial to yeast growth and ethanol production [11]. Therefore, the addition of molasses to SCB ethanol production may enhance the resulting ethanol concentration. In this study, molasses was first co-fermented with pretreated SCB at a ratio of $1: 3$ (mixture A) with various solid loadings of $12 \%, 16 \%$, $20 \%, 24 \%, 28 \%$, and $32 \%$, and the results are presented in Fig. 2a. With the existing of fermentable sugar in molasses, significant differences of fermentation rates in the first $12 \mathrm{~h}$ could be observed between the pretreated SCB alone and mixture $\mathrm{A}(p<0.05)$. The fermentation rates of mixtures $A$ in the first $12 \mathrm{~h}$ were higher $(1.39-2.61 \mathrm{~g} / \mathrm{L} / \mathrm{h})$ than those of those pretreated SCB $(0.78-1.61 \mathrm{~g} / \mathrm{L} / \mathrm{h})$. Furthermore, the ethanol concentration of mixtures $\mathrm{A}$ increased sharply from 0 to $24 \mathrm{~h}$, and then rose steadily until it reached the highest value. When the solid loading was increased from 12 to $24 \%$, the ethanol concentration did not present distinctive differences after $48 \mathrm{~h}$. However, for substrates fermented at loadings of $28 \%$ or $32 \%$, the ethanol concentration displayed different increased over time but increased gradually until $120 \mathrm{~h}$. When the
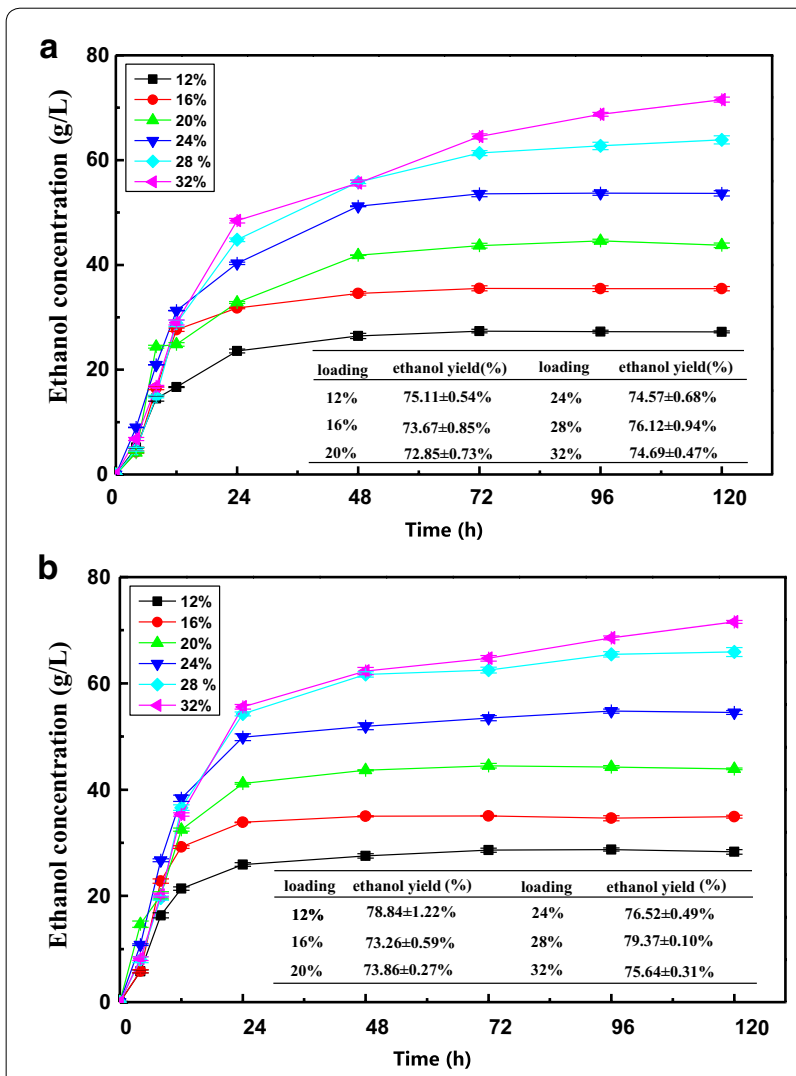

Fig. 2 Ethanol concentrations and yields of SCB and molasses mixtures (a 1:3, b 1:1) at different solid loadings in SSF ratios of molasses and pretreated SCB were 1:3 (mixtures A), the liquidity of the system was not improved, and it remained difficult to effectively saccharify and ferment SCB at an increasing solid loadings in batch mode. To further increase the ethanol yield, more molasses was added to the pretreated $\mathrm{SCB}$, with a ratio of 1:1 (mixtures B). Mixtures B had a similar variation tendency as did mixtures $\mathrm{A}$ in the first $24 \mathrm{~h}$ (Fig. 2b). In the first $12 \mathrm{~h}$ of SSF, there was a better fermentation rate when more molasses was added, with an ethanol productivity of $1.78-3.19 \mathrm{~g} / \mathrm{L} / \mathrm{h}$, than was seen for mixtures $\mathrm{A}$ and pretreated SCB. The higher ethanol yield of mixtures $B$ in the first $12 \mathrm{~h}$ of SSF can be explained by its higher fermentable sugars content, which was provided by molasses in the fermentation broth. For mixtures B, when the solid loading was increased from 12 to $24 \%$, the ethanol concentration stabilized after $24 \mathrm{~h}$; even with loadings of $28 \%$ and $32 \%$, the rate of fermentation slowed from 48 to $72 \mathrm{~h}$, indicating that most of the released fermentable sugars were converted to ethanol.

As expected, the addition of molasses can markedly improve the liquidity of the system and shorten the fermentation process. The maximum ethanol concentration of mixtures A and B was $71.54 \mathrm{~g} / \mathrm{L}$ and $71.72 \mathrm{~g} / \mathrm{L}$, with ethanol yields of $74.69 \%$ and $75.64 \%$, respectively, which were higher than those of the pretreated SCB $(62.01 \mathrm{~g} / \mathrm{L}$, $64.1 \%)$. These results are attributed to the good growth environment of the mixed substrates and the high hydrolysis rate of cellulase in a relative low loading of lignocellulosic substrates [7]. It was concluded that mixture B (1:1) was optimal and worthy of further research regarding a higher solid content to further boost the ethanol concentration in batch mode, which is described in the next section.

\section{The co-fermentation of pretreated SCB and molasses at high solid loadings in batch mode}

The co-fermentation of pretreated SCB and molasses was carried out at a ratio of 1:1 at high solid loadings of $36 \%$, $40 \%, 44 \%$, and $48 \%$. The results are displayed in Fig. 3. The increasing trends of ethanol concentration were nearly the same as that of mixtures A and mixtures B at $12 \%$ to $32 \%$ solid loading (Fig. 2). A rapid increase was observed in the first fermentation of $24 \mathrm{~h}$, and almost the equal quantities of ethanol concentration were acquired. Thereafter, the ethanol concentration increased gradually, reaching $84.75 \mathrm{~g} / \mathrm{L}$ and $87.66 \mathrm{~g} / \mathrm{L}$ with solid loadings of $36 \%$ and $40 \%$, respectively. The highest final ethanol concentration $(94.20 \mathrm{~g} / \mathrm{L})$ was achieved at a solid loading of $44 \%$, with an ethanol yield of $72.37 \%$. At the solid loading of $48 \%$, an ethanol concentration of only $92.37 \mathrm{~g} / \mathrm{L}$ was obtained. The final ethanol yields after $120 \mathrm{~h}$ were $79.49 \%, 74.04 \%, 72.37 \%$, and $65.07 \%$ for $36 \%$, 


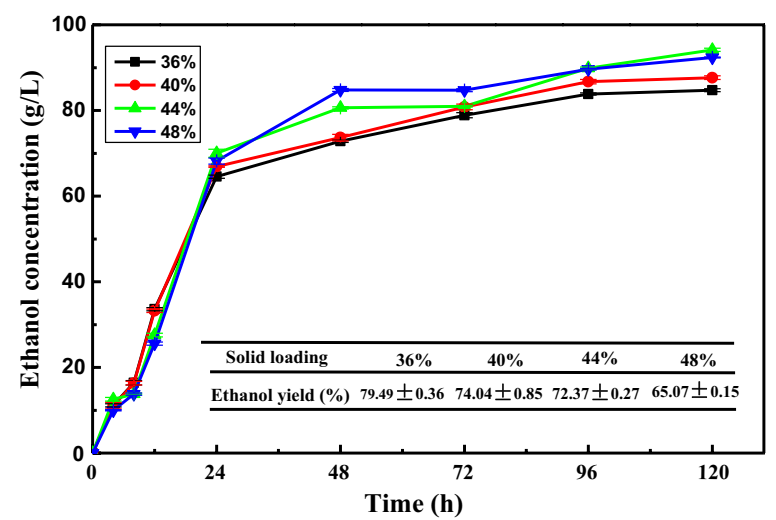

Fig. 3 Ethanol concentrations and yields of SCB and molasses mixture (1:1) at higher gravity fermentation

$40 \%, 44 \%$, and $48 \%$, respectively, decreasing gradually as the solid loading was increased. When the solid loading was increased to $48 \%$, the ethanol concentration did not increase but observably decreased, with a low ethanol yield of $65.07 \%$. This phenomenon can be attributed to the enhanced concentration of by-products and the increased viscosity of the mixed substrates, which impeded the enzymatic hydrolysis and yeast fermentation. One-way ANOVA was used to analyze the significant differences, and the results showed that the ethanol concentrations were significantly different between solid loadings of $36 \%, 40 \%, 44 \%$, and $48 \%(p<0.05)$. Similar results of high ethanol concentrations at increased solid loadings have been reported in the previous studies. Cunha et al. [35] obtained a high ethanol concentration $(93.0 \mathrm{~g} / \mathrm{L})$ with a mixture of Eucalyptus globulus wood and cheese whey powder at high temperature and solid loadings using the industrial Saccharomyces cerevisiae Ethanol $\operatorname{Red}^{\circledR}$ strain. Dayanand et al. obtained $83.2 \mathrm{~g} / \mathrm{L}$ ethanol from birch wood at a high solid loading in gradual fed-batch feeding mode [36].

Table 2 describes the byproducts (glycerol, lactic acid, and acetic acid) of the co-fermentation of pretreated SCB and molasses at high solid loadings. Changes in the concentrations of byproducts were similar. The overall concentration trend of byproducts was shown to be increasing when higher solid loadings were used in the SSF. Glycerol is an inhibitor of SSF, because it consumes approximately $4 \%$ of the substrate carbon source in the fermentation [37]. The highest glycerol concentrations were obtained after increasing gradually as the solid loading was increased. However, glycerol first increased and then slightly decreased as the fermentation time was prolonged. The highest concentration of $7.08 \mathrm{~g} / \mathrm{L}$ was obtained at $72 \mathrm{~h}$, with a solid loading of $48 \%$. The reduction of glycerol may be due to its conversion to
Table 2 Byproducts (glycerol, lactic acid, and acetic acid) of co-fermentation of SCB and molasses at higher loadings

\begin{tabular}{clllll}
\hline \multicolumn{5}{c}{$\begin{array}{l}\text { Loading } \\
\text { (\%) }\end{array}$} & \multicolumn{5}{l}{ Concentrations of byproducts } \\
\cline { 3 - 6 } & & $\mathbf{1 2} \mathbf{h}$ & $\mathbf{4 8} \mathbf{h}$ & $\mathbf{7 2} \mathbf{h}$ & $\mathbf{1 2 0} \mathbf{h}$ \\
\hline Glycerol & 36 & $4.25 \pm 0.15$ & $5.62 \pm 0.26$ & $5.38 \pm 1.01$ & $5.19 \pm 0.23$ \\
& 40 & $4.54 \pm 0.09$ & $6.14 \pm 0.76$ & $5.86 \pm 0.36$ & $5.22 \pm 0.10$ \\
& 44 & $4.06 \pm 0.79$ & $6.48 \pm 0.33$ & $6.2 \pm 0.10$ & $6.02 \pm 0.78$ \\
& 48 & $4.04 \pm 0.96$ & $7.08 \pm 0.13$ & $6.63 \pm 0.71$ & $6.49 \pm 1.00$ \\
Lactic & 36 & $4.15 \pm 0.26$ & $5.25 \pm 0.54$ & $3.84 \pm 0.39$ & $3.03 \pm 0.26$ \\
acid & 40 & $4.8 \pm 0.53$ & $4.48 \pm 0.46$ & $4.46 \pm 0.19$ & $3.99 \pm 0.13$ \\
& 44 & $5.17 \pm 0.03$ & $5.31 \pm 0.95$ & $4.68 \pm 0.57$ & $4.61 \pm 0.15$ \\
& 48 & $5.11 \pm 0.39$ & $5.67 \pm 0.63$ & $5.16 \pm 0.44$ & $4.62 \pm 0.55$ \\
Acetic & 36 & $1.99 \pm 0.20$ & $2.02 \pm 0.10$ & $2.10 \pm 0.50$ & $1.91 \pm 0.19$ \\
acid & 40 & $2.01 \pm 0.05$ & $2.05 \pm 0.06$ & $2.12 \pm 0.04$ & $2.12 \pm 0.55$ \\
& 44 & $2.04 \pm 0.13$ & $2.02 \pm 0.11$ & $2.1 \pm 0.13$ & $2.12 \pm 0.43$ \\
& 48 & $2.03 \pm 0.30$ & $2.12 \pm 0.30$ & $2.12 \pm 0.21$ & $2.22 \pm 0.29$ \\
\hline
\end{tabular}

dihydroxyacetone [38]. More lactic acid in the production would result in a decrease of the final ethanol concentration [25]. Lactic acid reached its highest value after $48 \mathrm{~h}$, before falling slightly. The final concentration of lactic acid for $44 \%$ and $48 \%$ loading was quite similar, which was likely because of the lower utilization of substances by the lactic acid bacteria at high loadings. The inhibiting effect of acetic acid is related to the $\mathrm{pH}$ of the fermentation broth; when the $\mathrm{pH}$ is lowered to 4.5 and below, a lower concentration of acetic acid can reduce the final ethanol titer or even completely impede ethanol production [39]. Cantarella et al. [40] found that acetic acid concentrations of more than $2 \mathrm{~g} / \mathrm{L}$ reduced the yield of ethanol fermentation when the $\mathrm{pH}$ of SSF was controlled at 4.8. Hanmilton et al. [41] considered that the influence of acetic acid was altogether the result of released protons and accumulated anions. The acetic acid concentration at solid loadings of $40 \%$ to $48 \%$ all exceeded $2 \mathrm{~g} / \mathrm{L}$, indicating that higher solid loadings had a negative effect on ethanol yield. The concentrations of glycerol, lactic acid, and acetic acid were all increased upon increasing solid loadings, which lead to lower ethanol production. To reduce the cost of distillation and minimize the effects of by-products caused by a high solids system, a solid loading of $36 \%$ may be a better choice for the co-fermentation of pretreated SCB and molasses, with a ratio of 1:1, to obtain higher ethanol titers.

\section{Anaerobic digestion of the residual stillage to produce biogas}

After SSF, the ethanol was removed by evaporation, and the residual stillage of the batch system $(36 \% \mathrm{w} / \mathrm{w})$ was subjected to methane production by anaerobic digestion. 
Figure 4 illustrates the accumulated methane production in $\mathrm{mL} / \mathrm{gVS}$ under the standard temperature and pressure conditions. In general, there are four degradation stages during anaerobic digestion: hydrolysis, acidogenesis, acetogenesis or dehydrogenation, and methanation [42]. However, the fermentation residue mainly contained non-fermentable sugars, such as pentose, which cannot be used by general yeast strains, as well as fermentation byproducts (glycerol, lactic acid, and acetic acid). The rate of methane production was faster in the first 4 days, with a value of $66.31 \mathrm{~mL} / \mathrm{g}$ VS per day. After this time, it rose modestly until halting. The final VS degradation efficiency of $95.93 \%$ indicated that the inoculum was easily adapted to the fermentation substrates, as discussed above. A final methane yield of $312.14 \mathrm{~mL} / \mathrm{g}$ VS was obtained after 30 days, which was in accordance with the previous reports. Liu et al. [43] evaluated sequential bioethanol and biogas production based on high solids' SSF and obtained $306.97 \mathrm{~mL} / \mathrm{gVS}$ methane from alkalipretreated SCB. The result achieved in this thesis was likely due to the high organic content in molasses and mixed substrate characteristics. After anaerobic digestion, the COD removal efficiency was $85.9 \%$, with an initial concentration of $13,500 \mathrm{mg} / \mathrm{L}$. Several similar studies have reported COD removal of 70-95\% from the biogas production of various stillage types [44]. The high COD removal values resulted in high methane production, and it was concluded that most of the organic substrates were effectively converted to biogas.

Based on the heating values of $30.0 \mathrm{~kJ} / \mathrm{g}$ (ethanol) and $35.9 \mathrm{~kJ} / \mathrm{L}$ (methane), the energy values achieved from the co-production of ethanol and biomethane were $253.2 \mathrm{~kJ}$ and $128.5 \mathrm{~kJ}$, respectively, which were higher than when producing only bioethanol. Dayanand et al. [36] observed a higher yield in the ethanol and biogas production from birch wood than when producing either ethanol or biogas

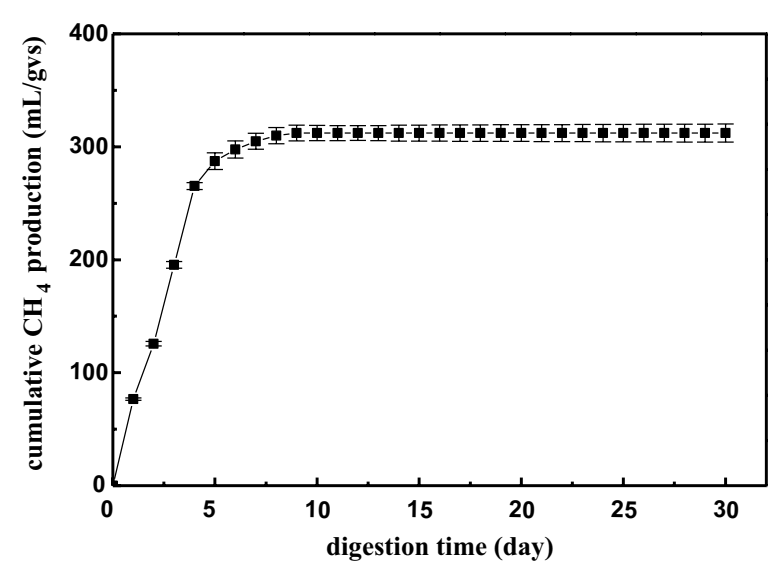

Fig. 4 Total methane production by anaerobic digestion after SSF alone. Similarly, Cavka et al. [45] demonstrated that the co-production of biofuels from hemp stem was more than twice the energy values of ethanol production alone. Mass balance is necessary to evaluate the overall process of biofuel production from biomass. A total of $1800 \mathrm{~g}$ of pretreated SCB and $1800 \mathrm{~g}$ of molasses were mixed, and the sequential bioethanol and biogas production was calculated. The calculated ethanol and biogas generation was $847 \mathrm{~g}$ and $596.6 \mathrm{~L}$, respectively. Biofuels are more sustainable and environmental friendly than fossil fuels. They can reduce greenhouse gas emissions and help to relieve the energy crisis. Based on this viewpoint, distilled stillage was more favorable for anaerobic digestion.

\section{Conclusions}

Integrating sugarcane molasses into SCB ethanol production not only increased the final ethanol concentration but also obtained a suitable conversion rate. Compared to pretreated SCB fermentation alone, the addition of molasses showed greater advantages by improving the liquidity of the system, shortening the fermentation time, and yielding higher ethanol production. At a mixture ratio of $1: 1$, the highest ethanol concentration of $94.20 \mathrm{~g} / \mathrm{L}$ was obtained at a solid loading of $44 \%$, with a fermentation yield of $72.37 \%$. After distillation, biogas production from the residual stillage was conducted by anaerobic digestion, yielding $312.14 \mathrm{~mL}$ methane/g VS within 30 days, resulting in the removal of $85.9 \%$ COD. Thus, the sequential production of bioethanol and biogas allows us to achieve a comprehensive utilization of biomass resources with associated environmental benefits.

\section{Methods \\ Materials}

The SCB and molasses used in this study were collected in the month of December from Maoyuan Sugar Co., Ltd., in Shaoguan, China. SCB was first milled into $<1 \mathrm{~mm}$ lengths with a MiniMill (MF10, IKA, Germany), sealed in a sealing bag, and stored at room temperature. The molasses sample was kept at $4{ }^{\circ} \mathrm{C}$ in a refrigerator for further utilization. The chemical compositions of untreated and pretreated SCB were determined using the method provided by the NREL [46]. The fermentation sugars in molasses were quantified by a highperformance liquid chromatography system (HPLC, Shimadzu, Japan) equipped with a refractive index detector (RID) and a cation-exchange column (SUGAR KS-801; 300 mm* $8.0 \mathrm{~mm}$; Shodex ${ }^{\mathrm{TM}}$, Japan). The compositions of SCB and molasses are shown in Table 1.

Cellulase (Cellic CTec2) was obtained from Novozymes (Bagswade, Denmark), with an enzyme activity of $164 \mathrm{FPU} / \mathrm{mL}$ according to the methods of NREL [47]. 
The microorganism strain Saccharomyces cerevisiae was provided by Angel Yeast Co., Ltd. (Yichang, China).

\section{Alkaline pretreatment}

Alkali pretreatment of SCB was performed in a roundbottom flask. An aliquot of $50 \mathrm{~g}$ SCB (dry basis) was added to $1 \mathrm{~L}$ of $0.5 \mathrm{M} \mathrm{NaOH}$ and incubated at $80^{\circ} \mathrm{C}$ for $2 \mathrm{~h}$ with $150 \mathrm{rpm}$. At the end of the pretreatment, the liquor and solid residues were separated by filtration. The slurry was washed with water until the washing liquid had a neutral $\mathrm{pH}$. The obtained residues were dried at $50{ }^{\circ} \mathrm{C}$ for $48 \mathrm{~h}$, and stored for composition analysis and subsequent fermentation processing.

\section{Simultaneous saccharification and fermentation (SSF)}

Before SSF, the dry yeast $(6.6 \mathrm{~g})$ was activated in a $2 \%$ glucose solution $(100 \mathrm{~mL})$ in two steps: $36^{\circ} \mathrm{C}$ for $10 \mathrm{~min}$ and $34{ }^{\circ} \mathrm{C}$ for $60 \mathrm{~min}$ in a shaker at $120 \mathrm{rpm}$. The SSF process was used in this research to convert biomass into ethanol. The alkali-pretreated SCB and molasses at various ratios was added into a $250 \mathrm{~mL}$ flask. The $\mathrm{pH}$ of the fermentation system was adjusted to 4.5 using $1.0 \mathrm{~mol} / \mathrm{L} \mathrm{H}_{2} \mathrm{SO}_{4}$. After autoclaving at $121{ }^{\circ} \mathrm{C}$ for $20 \mathrm{~min}$, certain amounts of cellulase (15 FPU/g pretreated SCB) and activated yeast $(5 \mathrm{~mL})$ were added into the system [6]. A specified volume of sterile water was then added to the mixture to reach $100 \mathrm{~mL}$ of liquor. The fermentation was performed at $34{ }^{\circ} \mathrm{C}$ and $120 \mathrm{rpm}$ for $120 \mathrm{~h}$ in a shaker. SSF trials were conducted in triplicate, and the results are reported as mean values.

During SSF, the quantities of sugars and ethanol collected at different times were determined by HPLC using a refractive index detector (RID) and a cation-exchange column (SUGAR SH1011; $300 \mathrm{~mm} * 8.0 \mathrm{~mm}$; Shodex ${ }^{\mathrm{TM}}$, Japan). $0.05 \mathrm{M} \mathrm{H}_{2} \mathrm{SO}_{4}$ was used as the mobile phase with a flow rate of $1 \mathrm{~mL} / \mathrm{min}$ at column temperature of $50{ }^{\circ} \mathrm{C}$. The byproducts (glycerol, lactic acid, and acetic acid) were separated using an HPLC system equipped with a Prominence UV/Vis detector (SPD) and an ion-exchange column (SUPELCOGEL C-610H; 300 mm* $7.8 \mathrm{~mm}$; Sho$\mathrm{dex}^{\mathrm{TM}}$, Japan). In theory, $1 \mathrm{~g}$ of cellulose can be hydrolyzed into $1.11 \mathrm{~g}$ of glucose and that $1 \mathrm{~g}$ of glucose can be converted into $0.511 \mathrm{~g}$ of ethanol during the SSF process [48]. The ethanol yield was calculated based on the following equation:

$$
\text { Ethanol yield }(\%)=\frac{\text { Actual ethanol released }}{\text { Theoretical ethanol release }} \times 100 \% \text {. }
$$

\section{Biogas production}

Ethanol from the fermentation medium was collected using a rotary evaporator at $60{ }^{\circ} \mathrm{C}$ for $30 \mathrm{~min}$ under reduced pressure. The residues in the stillage were used in the subsequent biogas production experiments. Biological methane potential (BMP) detection was conducted in triplicate using the Bioprocess Control AMPTS II (automatic methane potential test system). The experiments were performed in $500 \mathrm{~mL}$ sealed batch flasks with a working volume of $400 \mathrm{~mL}$ at $37^{\circ} \mathrm{C}$ for 30 days, in which the mixed ratio of substrates and inoculum was 1:1 based on the VS amount in grams.

The inoculum, obtained from our laboratory, was trained chronically in a mesophilic anaerobic tank with total solids (TS) $6.74 \%$, volatile solids (VS) $1.18 \%$, and a $\mathrm{pH}$ of 7.3-7.5. Before starting the assay tests, the inoculum was incubated in a starving condition at $37^{\circ} \mathrm{C}$ for 1 week to lessen the endogenous biogas production. Pure $\mathrm{N}_{2}$ was introduced into the headspace of the bottle for 3-5 min to ensure anaerobic conditions. A blank sample consisting of pure inoculum and a contrast sample consisting of pure microcrystalline cellulose were used as controls. The experiments were carried out until no gas was detected.

Samples were withdrawn at different times for determining the constituent elements. During the biogas production process, the determinations of TS, VS, COD, and ammonium nitrogen $\left(\mathrm{NH}_{4}-\mathrm{N}\right)$ were based on the methods provided by a previous report [49], and the $\mathrm{pH}$ was measured using a $\mathrm{pH}$ meter (Five Easy Plus, MettlerToledo, Australia).

\section{Statistical analysis}

Analysis of standard errors and variance was performed using SPSS version 16.0. Statistical differences in the ethanol concentrations among the different solid loadings and in the fermentation rates between pure SCB and the mixtures were analyzed using one-way ANOVA. "significant" was used when the $p$ value $<0.05$.

\section{Abbreviations \\ SCB: sugarcane bagasse; VS: volatile solids; COD: chemical oxygen demand; SSF: simultaneous saccharification and fermentation; SHF: the separate hydrolysis and fermentation; HPLC: high-performance liquid chromatography; RID: refractive index detector; BMP: biological methane potential; AMPTS: automatic methane potential test system; TS: total solid; VS: volatile solid.}

\section{Authors' contributions}

MF completed performed the major experiments and prepared the manuscript. SZ and GY helped with analyzing the results. JX and HZ proofed data and text and gave guidance for formatting and submission of the paper. All authors read and approved the final manuscript.

\section{Acknowledgements}

This work was supported by the Science and Technology Planning Project of Guangdong Province in China (2017B020238005 and 2015B020215011), the National Science and Technology Support Project of China (2015BAD15B03 and 2015BAD21B03), and the National Natural Science Foundation of China (21606091). 


\section{Competing interests}

The authors declare that they have no competing interests.

\section{Availability of data and materials}

All data generated during this study are included in this published article and its additional file.

\section{Consent for publication}

All the authors consented on the publication of this work.

\section{Ethics approval and consent to participate}

Not applicable.

\section{Funding}

Funding sources have been addressed in the acknowledgements.

\section{Publisher's Note}

Springer Nature remains neutral with regard to jurisdictional claims in published maps and institutional affiliations.

Received: 18 September 2018 Accepted: 1 December 2018

Published online: 18 December 2018

\section{References}

1. Cardona CA, Sánchez OJ. Fuel ethanol production: process design trends and integration opportunities. Bioresour Technol. 2007;98:2415-57.

2. Menon V, Rao M. Trends in bioconversion of lignocellulose: biofuels, platform chemicals \& biorefinery concept. Prog Energy Combust Sci. 2012;38:522-50.

3. Feng X, Jian S, Konda NVSNM, Jian S, Dutta T, Scown CD, et al. Transforming biomass conversion with ionic liquids: process intensification and the development of a high-gravity, one-pot process for the production of cellulosic ethanol. Energy Environ Sci. 2016;9:1042-9.

4. Oke MA, Annuar MSM, Simarani K. Mixed feedstock approach to lignocellulosic ethanol production - prospects and limitations. Bioenergy Res. 2016;9:1189-203.

5. Xu Y, Wang D. Integrating starchy substrate into cellulosic ethanol production to boost ethanol titers and yields. Appl Energy. 2017;195:196-203.

6. Ye G, Zeng D, Zhang S, Fan M, Zhang H, Xie J. Ethanol production from mixtures of sugarcane bagasse and Dioscorea composita extracted residue with high solid loading. Bioresour Technol. 2018;257:23.

7. Erdei B, Barta Z, Sipos B, Réczey K, Galbe M, Zacchi G. Ethanol production from mixtures of wheat straw and wheat meal. Biotechnol Biofuels. 2010;3:16.

8. Damay J, Boboescu IZ, Duret X, Lalonde O, Lavoie JM. A novel hybrid first and second generation hemicellulosic bioethanol production process through steam treatment of dried sorghum biomass. Bioresour Technol. 2018;263:103-11

9. Na Y, LiT, Sun ZY, Tang YQ, Kida K. Production of bio-ethanol by integrating microwave-assisted dilute sulfuric acid pretreated sugarcane bagasse slurry with molasses. Appl Biochem Biotechnol. 2017;185:191-206.

10. Leibbrandt $\mathrm{NH}$, Knoetze JH, Görgens JF. Comparing biological and thermochemical processing of sugarcane bagasse: an energy balance perspective. Biomass Bioenergy. 2011;35:2117-26.

11. Chotineeranat S, Wansuksri R, Piyachomkwan K, Chatakanonda P, Weerathaworn $\mathrm{P}$, Sriroth K. Effect of calcium ions on ethanol production from molasses by Saccharomyces cerevisiae. Sugar Tech. 2010;12:120-4.

12. Jimenez AM, Borja R, Martin A. A comparative kinetic evaluation of the anaerobic digestion of untreated molasses and molasses previously fermented with Penicillium decumbens in batch reactors. Biochem Eng. 2004;18:121-32.

13. Kumar P, Barrett DM, Delwiche MJ, Stroeve P. Methods for pretreatment of lignocellulosic biomass for efficient hydrolysis and biofuel production. Ind Eng Chem Res. 2009;48:3713-29.

14. Hongzhang $C$, Junying $Z$. Clean production technology of integrated pretreatment for lignocellulose. Afr J Agric Res. 2013;8:339-48.
15. Behera S, Arora R, Nandhagopal N, Kumar S. Importance of chemical pretreatment for bioconversion of lignocellulosic biomass. Renew Sustain Energy Rev. 2014;36:91-106.

16. Karp SG, Woiciechowski AL, Soccol VT, Soccol CR. Pretreatment strategies for delignification of sugarcane bagasse: a review. Braz Arch Biol Technol. 2013;56:679-89.

17. Mcintosh S, Vancov T. Enhanced enzyme saccharification of Sorghum bicolor straw using dilute alkali pretreatment. Bioresour Technol. 2010;101:6718-27.

18. Viruthagiri T, Sasikumar E. Simultaneous saccharification and fermentation of recycled paper sludge for ethanol production. Asian J Microbiol Biotechnol Environ. 2007:9:587-90.

19. Kang HW, Kim Y, Kim SW, Choi GW. Cellulosic ethanol production on temperature-shift simultaneous saccharification and fermentation using the thermostable yeast Kluyveromyces marxianus CHY1612. Bioprocess Biosyst Eng. 2012;35:115-22.

20. Jin W, Chen L, Hu M, Sun D, Li A, Li Y, et al. Tween-80 is effective for enhancing steam-exploded biomass enzymatic saccharification and ethanol production by specifically lessening cellulase absorption with lignin in common reed. Appl Energy. 2016;175:82-90.

21. Fan Z, South C, Lyford K, Munsie J, Van WP, Lynd LR. Conversion of paper sludge to ethanol in a semicontinuous solids-fed reactor. Bioprocess Biosyst Eng. 2003;26:93.

22. Mohagheghi A, Tucker M, Grohmann K, Wyman C. High solids simultaneous saccharification and fermentation of pretreated wheat straw to ethanol. Appl Biochem Biotechnol. 1992;33:67-81.

23. Liu ZH, Qin L, Zhu JQ, Li BZ, Yuan YJ. Simultaneous saccharification and fermentation of steam-exploded corn stover at high glucan loading and high temperature. Biotechnol Biofuels. 2014;7:167.

24. Olofsson K, Bertilsson M, Lidén G. A short review on SSF-an interesting process option for ethanol production from lignocellulosic feedstocks. Biotechnol Biofuels. 2008;1:7.

25. Tang Y, Zhao D, Cristhian C, Jiang J. Simultaneous saccharification and cofermentation of lignocellulosic residues from commercial furfural production and corn kernels using different nutrient media. Biotechnol Biofuels. 2011:4:22

26. Wang TT, Sun ZY, Huang YL, Tan L, Tang YQ, Kida K. Biogas production from distilled grain waste by thermophilic dry anaerobic digestion: pretreatment of feedstock and dynamics of microbial community. Appl Biochem Biotechnol. 2017;184:1-18.

27. Haandle AC, Catunda PFC. profitability increase of alcohol distilleries by the rational use of byproducts. Water Sci Technol. 1994;29:191-5.

28. Fuess LT, Garcia ML. Anaerobic digestion of stillage to produce bioenergy in the sugarcane-to-ethanol industry. Environ Technol. 2014;35:333-9.

29. Kopetz H. Renewable resources: build a biomass energy market. Nature. 2013;494:29.

30. Guo M, Song W, Buhain J. Bioenergy and biofuels: history, status, and perspective. Renew Sustain Energy Rev. 2015;42:712-25.

31. Cardona CA, Quintero JA, Paz IC. Production of bioethanol from sugarcane bagasse: status and perspectives. Bioresour Technol. 2010;101:4754-66

32. Zhang $\mathrm{Q}$, Wei $\mathrm{Y}$, Han $\mathrm{H}$, Weng $\mathrm{C}$. Enhancing bioethanol production from water hyacinth by new combined pretreatment methods. Bioresour Technol. 2017;251:358.

33. Jørgensen $H$, Vibepedersen J, Larsen J, Felby C. Liquefaction of lignocellulose at high-solids concentrations. Biotechnol Bioeng. 2007;96:862.

34. Svensson E, Lundberg $V$, Jansson M, Xiros C, Berntsson T. The effect of high solids loading in ethanol production integrated with a pulp mill. Chem Eng Res Des. 2016;111:387-402.

35. Cunha M, Romaní A, Carvalho M, Domingues L. Boosting bioethanol production from Eucalyptus wood by whey incorporation. Bioresour Technol. 2017;250:256-64.

36. Kalyani DC, Müller G, Zamanzadeh M, Horn SJ. Biofuel production from birch wood by combining high solid loading simultaneous saccharification and fermentation and anaerobic digestion. Appl Energy. 2017;193:210-9.

37. Li J, Yu HL, Liu ZP, Jiang JX, Sun DF. Enhanced ethanol production with mixed lignocellulosic substrates from commercial furfural and cassava residues. Bioresources. 2015;10:1162-73. 
38. Shams YS, Gonzalez R. Engineering Escherichia coli for the efficient conversion of glycerol to ethanol and co-products. Metab Eng. 2008;10:340-51.

39. Graves T, Narendranath NV, Dawson K, Power R. Effect of pH and lactic or acetic acid on ethanol productivity by Saccharomyces cerevisiae in corn mash. J Ind Microbiol Biotechnol. 2006;33:469-74.

40. Cantarella M, Cantarella L, Gallifuoco A, Spera A, Alfani F. Effect of inhibitors released during steam-explosion treatment of poplar wood on subsequent enzymatic hydrolysis and SSF. Biotechnol Prog. 2004:20:200.

41. Hamilton T, Roe J, Hayes C, Webster A. Effects of ammonia inhalation and acetic acid pretreatment on colonization kinetics of toxigenic Pasteurella multocida within upper respiratory tracts of swine. J Clin Microbiol. 1998:36:1260-5

42. Mao C, Feng $Y$, Wang $X$, Ren G. Review on research achievements of biogas from anaerobic digestion. Renew Sustain Energy Rev. 2015:45:540-55.

43. Liu YY, Xu JL, Yu Z, Yuan ZH, He MC, Liang CY, et al. Sequential bioethanol and biogas production from sugarcane bagasse based on high solids fed-batch SSF. Energy. 2015;90:1199-205.
44. Hutnan M, Hornak M, Bodík I, Hlavacka V. Anaerobic treatment of wheat stillage. Chem Biochem Eng Q. 2003;17:233-41.

45. Cavka A. Detoxification of lignocellulosic hydrolysates using sodium borohydride. Bioresour Technol. 2013;136:368-76.

46. Sluiter A, Hames B, Ruiz R, Scarlata C, Sluiter J, Templeton D, et al. Determination of structural carbohydrates and lignin in biomass. Lab Anal Proced. 2008;1617:1-16.

47. Adney B, Baker J. Measurement of cellulase activities. Lab Anal Proced. 1996;6:1996

48. Palmqvist E, Hahnhägerdal B. Fermentation of lignocellulosic hydrolysates. II: inhibitors and mechanisms of inhibition. Bioresour Technol. 2000;74:25-33.

49. Eaton A, Clesceri LS, Rice EW, Greenberg AE, Franson M. APHA: standard methods for the examination of water and wastewater. Centennial ed. Washington, DC: APHA, AWWA, WEF; 2005.
Ready to submit your research? Choose BMC and benefit from:

- fast, convenient online submission

- thorough peer review by experienced researchers in your field

- rapid publication on acceptance

- support for research data, including large and complex data types

- gold Open Access which fosters wider collaboration and increased citations

- maximum visibility for your research: over $100 \mathrm{M}$ website views per year

At BMC, research is always in progress.

Learn more biomedcentral.com/submissions 